\title{
The main spoilage-related psychrotrophic bacteria in refrigerated raw milk
}

\author{
J. C. Ribeiro Júnior, ${ }^{* 1}$ A. M. de Oliveira, ${ }^{*}$ F. de G. Silva, ${ }^{*}$ R. Tamanini, ${ }^{*}$ A. L. M. de Oliveira, $†$ and V. Beloti ${ }^{*}$ \\ ${ }^{*}$ Animal Products Inspection Laboratory, and \\ †Biochemistry and Biotechnology Department, State University of Londrina, Paraná, 86.057-970, Brazil
}

\begin{abstract}
Refrigerated raw milk may contain psychrotrophic microorganisms that produce thermoresistant exoproteases and lipases, which may compromise the quality of processed fluid milk and dairy products during storage. The aim of this work was to quantify and identify the deteriorating psychrotrophic microbiota in Brazilian refrigerated raw milk using genetic diversity analysis. The mean psychrotrophic count was $1.1 \times 10^{4} \mathrm{cfu} / \mathrm{mL}$. Of the total isolates, 47.8 and $29.8 \%$ showed deteriorating activity at $35^{\circ} \mathrm{C}$ within $48 \mathrm{~h}$ and $7^{\circ} \mathrm{C}$ within 10 $\mathrm{d}$, respectively. Among the proteolytic species, more isolated by this study were Lactococcus lactis (27.3\%), Enterobacter kobei (14.8\%), Serratia ureilytica (8\%), Aerococcus urinaeequi (6.8\%), and Bacillus licheniformis $(6.8 \%)$. Observed among lipolytics were E. kobei (17.7\%), L. lactis (15.6\%), A. urinaeequi (12.5\%), and Acinetobacter lwoffii (9.4\%). The isolates S. ureilytica, E. kobei, Pseudomonas spp., and Yersinia enterocolitica potentially produced alkaline metalloprotease $(\operatorname{apr} X)$. Despite the low counts, a considerable portion of the psychrotrophic microbiota presented spoilage potential, which reaffirms the need for rigor in the control of contamination and the importance of rapid processing as factors that maintain the quality of milk and dairy products.
\end{abstract}

Key words: alkaline metalloprotease, lipolytic, milk spoiler, proteolytic

\section{INTRODUCTION}

The cooling of raw milk allows for control of the multiplication of mesophyll microbiota, predominantly saccharolytic microorganisms (Das et al., 2015; Erich et al., 2015). These microorganisms are responsible for the acidification and thermal instability of milk proteins, as the hydrolysis of lactose produces lactic acid as a by-product (McAuley et al., 2016).

Received April 24, 2017.

Accepted August 21, 2017.

${ }^{1}$ Corresponding author: ribeirojuniorjc@gmail.com
Some mesophilic microorganisms, called psychrotrophs, adapt to refrigeration temperatures by synthesizing phospholipids and neutral lipids containing increased proportions of UFA, resulting in a reduction in the melting point of the lipids. This phenomenon serves to maintain their fluidity, thus allowing the continued functionality, solute transport, and secretion of extracellular enzymes (de Oliveira et al., 2015).

Some psychrotrophs produce and release proteases and lipases to the external environment and absorb the products of their hydrolysis (Cousin, 1982). In addition to compromising the integrity of the milk constituents, the microbial proteases and lipases are thermostable and can remain active even after the elimination of the vegetative microorganisms by heat treatments applied to the milk by the industry (Samarzija et al., 2012; de Oliveira et al., 2015; Baglinière et al., 2017). Prolonged action of proteases and lipases may cause organoleptic changes in fluid milk or dairy products, such as a bitter or rancid taste in cheeses or gelation and sedimentation in UHT-treated milk (Fairbairn and Law, 1986; Matéos et al., 2015; Zhang et al., 2015).

There is a global demand for dairy products with good quality and a long shelf-life. For pasteurized milk, which best preserves the nutritional and organoleptic aspects of raw milk (Andersson and Öste, 1994), there is an expectation of increased shelf life. For this to happen, it is necessary to keep contamination to a minimum and to control for specific microorganisms with high potential for spoilage.

Several studies evaluated the composition of psychrotrophic microbiota in raw milk and its deteriorating activity (Hantsis-Zacharov and Halpern, 2007; McPhee and Griffiths, 2011; Gargouri et al., 2013; von Neubeck et al., 2015; Vithanage et al., 2016; Xin et al., 2017). However, different microbial community structures are found in raw cow milk samples from different geographical areas (Xin et al., 2017), and under good environmental hygiene conditions in obtaining raw milk, other proteolytic and lipolytic psychrotrophic microorganisms can become important for milk quality. Studies that verify the diversity of these other microorganisms are essential to determine their dairy farm of origin and 
refine hygiene practices used to further reduce these specific microorganisms in raw milk. These practices could result in minimizing the effect of proteases and lipases in processed milk, thereby increasing its shelf life, the integrity of its constituents, and consequently, the industrial yield.

The aims of this study were to quantify psychrotrophic microorganisms in Brazilian refrigerated raw milk, to verify the proteolytic and lipolytic activity of the isolates at mesophilic and psychrotrophic temperatures, to ascertain the potential of alkaline metalloprotease production, and to identify these contaminant microorganisms.

\section{MATERIALS AND METHODS}

We evaluated 20 refrigerated raw milk samples produced in the municipalities of Castro and Arapoti, in the central region of the state of Paraná, Southern Brazil. Each sample was collected from a different farm. These dairy farms were previously characterized (Ribeiro Júnior et al., 2015) and are part of the largest association of milk producers in southern Brazil. The milk produced on these farms is sent to the dairy company of the association for the production of noble dairy products and fluid milk. The samples were aseptically collected from the bulk tanks on the dairy farms and transported under refrigeration to the Laboratório de Inspeção de Produtos de Origem Animal of the State University of Londrina, Paraná, Brazil.

The raw milk samples were diluted until $10^{-3}$ in saline $(0.9 \%)$ and peptone $(0.01 \%)$ for total bacterial count (TBC), performed by seeding into Petrifilm AC (3M Microbiology, Maplewood, MN), followed by incubation at $35 \pm 1^{\circ} \mathrm{C}$ for $48 \mathrm{~h}$. The psychrotrophic count was performed by adding samples $(0.1 \mathrm{~mL})$ in duplicate on the surface of plate count agar (Oxoid, Basingstoke, UK). The plates were inverted and incubated at $7^{\circ} \mathrm{C}$ for $10 \mathrm{~d}$.

All bacterial colonies on the plates used for counting psychrotrophs (one plaque from the duplicate) were purified in plates of standard agar and were retested on milk agar (Acumedia, Baltimore, MD) supplemented with $10 \%$ reconstituted skim milk powder solution $(10 \%)$ and on tributyrin agar (HiMedia, Mumbai, India) supplemented with $1 \%$ tributyrin (HiMedia) to verify the proteolytic and lipolytic potential, respectively (Hantsis-Zacharov and Halpern, 2007). Plates were incubated for $48 \mathrm{~h}$ at $35^{\circ} \mathrm{C}$ and for $10 \mathrm{~d}$ at $7^{\circ} \mathrm{C}$.

The isolates that presented with proteolytic or lipolytic activity (or both) were cultured in brain heart infusion broth (Acumedia, Baltimore, MD), incubated at $35^{\circ} \mathrm{C}$ for $48 \mathrm{~h}$, and subjected to genomic DNA extraction by simple boiling as in Ribeiro Júnior et al.
(2016). The products of the extraction of the isolates that presented proteolytic activity in the plates were subjected to PCR for the aprX gene to verify the alkaline metalloprotease production potential (Table 1).

All extracts were subjected to amplification of the internal transcribed spacer (ITS) region 16-23S rRNA using the primers and conditions described in Table 1. The PCR was performed with approximately $50 \mathrm{ng}$ of DNA template, $100 \mathrm{n} M$ of each deoxynucleotide, $5 \mu \mathrm{L}$ of $10 \times$ buffer, $75 \mathrm{mmol} \cdot \mathrm{L}^{-1}$ of $\mathrm{MgCl}_{2}, 20 \mathrm{pmol}$ $\mathrm{L}^{-1}$ of each primer, and $2.5 \mathrm{U}$ of Platinum Taq DNA polymerase (Invitrogen, Carlsbad, CA). Amplification was performed in a thermocycler (Aeris Thermal Cycler, Esco Micro Pte. Ltd., Singapore) and the PCRamplified DNA samples were loaded onto a $1 \%$ agarose gel (Invitrogen) to be subjected to electrophoresis for 1 $\mathrm{h}$ at a constant voltage of $90 \mathrm{~V}$. The gels were stained with an ethidium bromide solution of $0.2 \mathrm{mg} / \mathrm{mL}$ for 20 min before visualization. Images were saved after UV transillumination.

The amplicons of the ITS region were subjected to restriction by $2 \mathrm{U}$ via the enzyme Cfo I (Promega, Madison, WI), using the reaction protocol described by the manufacturer (https://www.promega.com/-/ media/files/resources/protocols/technical-manuals/ 101/restriction-enzymes-protocol.pdf). The amplified DNA and enzyme mixtures were incubated for $1 \mathrm{~h}$ at $37^{\circ} \mathrm{C}$ in a thermocycler. Restriction products were subjected to agarose gel electrophoresis (1.5\%) for 1 $\mathrm{h}$ at a constant voltage of $70 \mathrm{~V}$. The gels were stained with an ethidium bromide solution of $0.2 \mathrm{mg} / \mathrm{mL}$ and documented.

The amplification profiles of the ITS regions of each isolate, together with its product of restriction by the enzyme Cfo I, were used as genomic variables to construct a dendrogram of phylogenetic similarity (Ranjard et al., 2001) using Bionumerics v. 1.50 software (Applied Mathematics, Kortrijk, Belgium). The similarity matrix Dice coefficient (Dice, 1945) and the unweighted pair group mean averages algorithm (Sneath and Sokal, 1973) were used. To determine the clusters, a minimum of $70 \%$ phylogenetic similarity was used.

A representative sample from each cluster was selected for partial amplification of the 16S rRNA gene using the primers and conditions described in Table 1. The products of this PCR were purified (PureLink Genomic DNA Purification Kit, Invitrogen) and quantified (Qubit dsDNA HS Assay Kit, Invitrogen) for DNA sequencing using the Sanger method (ABI 3500 Genetic Analyzer, Applied Biosystems, Foster City, CA), which was completed in both directions.

The quality of the sequences was evaluated by the software BioEdit v. 7.2.5 (Hall, 1999), and the consensus sequences were generated by CAP 3 (Huang 


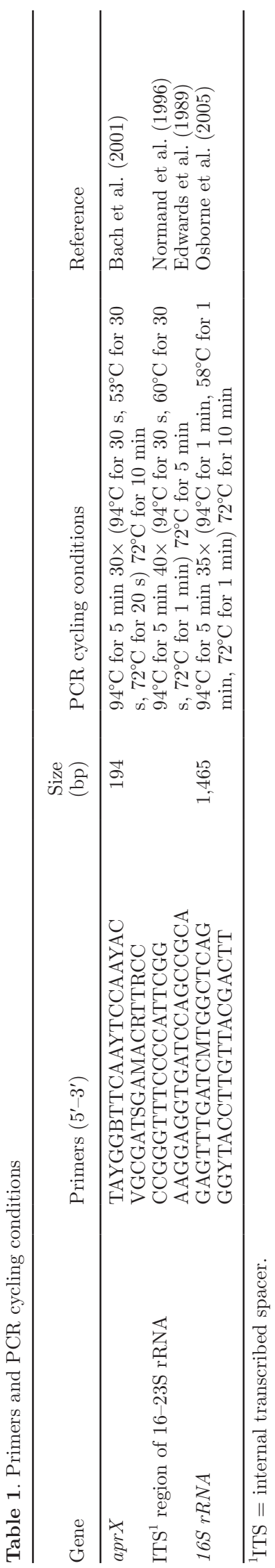

and Madan, 1999). These sequences were individually aligned using Clustal $\mathrm{W}$ and the representative sequences of each genus available in the Ribosomal Database Project, and genetic similarity was analyzed via the neighbor joining method and the Tamura-Nei model using bootstrap support for 1,000 replications in the MEGA v. 7.0 software (Kumar et al., 2016).

\section{RESULTS AND DISCUSSION}

The TBC of the raw milk samples varied from $6.8 \times$ $10^{2}$ to $1.5 \times 10^{5} \mathrm{cfu} / \mathrm{mL}$, with a mean of $1.5 \times 10^{4} \mathrm{cfu} /$ $\mathrm{mL}$. It was observed that $95 \%$ of the 20 milk samples have a TBC of less than $10^{5} \mathrm{cfu} / \mathrm{mL}$. Psychrotrophic counts ranged from $10^{1}$ to $2.1 \times 10^{5} \mathrm{cfu} / \mathrm{mL}$ with a mean of $1.1 \times 10^{4} \mathrm{cfu} / \mathrm{mL}$. Considering the mean values, the psychrotrophic count represents $78.3 \%$ of the TBC.

These results demonstrate the high microbiological quality of the samples, since the psychrotrophic count, a parameter considered by Ercolini et al. (2009) to determine the quality of raw milk samples in Italy, was higher than $10^{5} \mathrm{cfu} / \mathrm{mL}$ in only one sample. According to Matta et al. (1997), the deterioration of milk by psychrotrophs is perceptible when the count reaches $10^{6}$ $\mathrm{cfu} / \mathrm{mL}$.

Of the plaques used to count the 20 milk samples evaluated in the present study, only 295 isolates of psychrotrophic bacteria were obtained. The low recovery of strains was proportional to these low bacterial counts: of the 5 milk samples, only 3 isolates were obtained from each plate with no diluted raw milk samples. In total, $141(47.8 \%)$ colonies showed deteriorating milk activity at mesophilic incubation $\left(35^{\circ} \mathrm{C} / 48 \mathrm{~h}\right), 43(30.5 \%)$ were both proteolytic and lipolytic, and $45(31.9 \%)$ and 53 $(37.6 \%)$ were exclusively proteolytic or lipolytic, respectively (Table 2). At refrigeration temperature $\left(7^{\circ} \mathrm{C} / 10\right.$ d), $88(29.8 \%)$ colonies showed spoilage potential in the milk, $29(20.6 \%)$ and $38(27 \%)$ were proteolytic or lipolytic, respectively, and $21(14.9 \%)$ presented both deteriorating activities.

All deteriorating milk isolates were subjected to amplification of the ITS region, restriction digestion with the $C f o$ I enzyme, phylogenetic grouping for subsequent sequencing of the $16 \mathrm{~S}$ rRNA gene, and identification by clustering. The similarity dendrogram for the isolates that presented proteolytic activity is represented in Figure 1, where it is possible to observe the determination of 36 clusters with $70 \%$ similarity. Figure 2 shows the phylogenetic similarity dendrogram for the lipolytic microorganisms, in which 47 clusters were determined. Identification at the species level was not possible in 4 of the isolates (2 Pseudomonas, 1 Acinetobacter, and 1 Pantoea), as shown in Table 2. 
Table 2. Identification of spoilage microorganisms $(\mathrm{n}=141)$ among the total psychrotrophic microbiota $(\mathrm{n}=295)$ with proteolytic and lipolytic potential at 35 and $7^{\circ} \mathrm{C}$ of the strains from high microbiological quality Brazilian refrigerated raw milk

\begin{tabular}{|c|c|c|c|c|c|c|c|c|}
\hline \multirow[b]{2}{*}{$\begin{array}{l}16 \mathrm{~S} \text { rRNA clustering } \\
\text { identification }\end{array}$} & \multicolumn{2}{|c|}{ Total } & \multicolumn{2}{|c|}{ Proteolytic } & \multicolumn{2}{|c|}{ Lipolytic } & \multicolumn{2}{|c|}{$\begin{array}{l}\text { Proteolytic } \\
\text { and lipolytic }\end{array}$} \\
\hline & No. & $\%$ & $\begin{array}{l}35^{\circ} \mathrm{C} / 48 \mathrm{~h}, \\
\text { no. }(\%)\end{array}$ & $\begin{array}{l}7^{\circ} \mathrm{C} / 10 \mathrm{~d} \\
\text { no. }(\%)\end{array}$ & $\begin{array}{l}35^{\circ} \mathrm{C} / 48 \mathrm{~h}, \\
\text { no. }(\%)\end{array}$ & $\begin{array}{l}7^{\circ} \mathrm{C} / 10 \mathrm{~d} \\
\text { no. }(\%)\end{array}$ & $\begin{array}{l}35^{\circ} \mathrm{C} / 48 \mathrm{~h}, \\
\text { no. }(\%)\end{array}$ & $\begin{array}{l}7^{\circ} \mathrm{C} / 10 \mathrm{~d} \\
\text { no. }(\%)\end{array}$ \\
\hline Lactococcus lactis & 35 & 24.5 & $20(57.1)$ & $18(51.4)$ & $11(2.9)$ & $6(17.1)$ & $4(11.4)$ & $3(8.6)$ \\
\hline Enterobacter kobei & 22 & 15.4 & $5(22.7)$ & $2(9.1)$ & $9(40.9)$ & $7(31.9)$ & $8(36.4)$ & $3(13.6)$ \\
\hline Aerococcus urinaeequi & 12 & 8.4 & & $3(25)$ & $6(50)$ & $1(8.3)$ & $6(50)$ & $1(8.3)$ \\
\hline Serratia ureilytica & 8 & 5.6 & & & $1(12.5)$ & $1(12.5)$ & $7(87.5)$ & $6(75)$ \\
\hline Bacillus licheniformis & 7 & 4.9 & $5(71.4)$ & & $1(14.3)$ & $2(28.6)$ & $1(14.3)$ & \\
\hline Staphylococcus epidermidis & 7 & 4.9 & $2(28.6)$ & & $4(57.1)$ & $2(28.6)$ & $1(14.3)$ & $1(14.3)$ \\
\hline Macrococcus caseolyticus & 6 & 5.6 & $4(66.6)$ & $2(33.3)$ & $1(16.7)$ & & $1(16.7)$ & $2(33.3)$ \\
\hline Streptococcus parauberis & 5 & 3.5 & $2(40)$ & $2(40)$ & $1(20)$ & $1(20)$ & $2(40)$ & $1(20)$ \\
\hline Enterococcus faecium & 4 & 2.8 & & & $3(75)$ & $3(75)$ & $1(25)$ & $1(25)$ \\
\hline Acinetobacter johnsonii & 3 & 1.4 & & & $3(100)$ & $2(66.7)$ & & \\
\hline Acinetobacter spp. & 1 & 0.7 & & & $1(100)$ & $1(100)$ & & \\
\hline Bacillus cereus & 1 & 0.7 & $1(100)$ & & & $1(100)$ & & \\
\hline Bacillus pumilus & 1 & 0.7 & & & & & $1(100)$ & \\
\hline Enterococcus hermanniensis & 1 & 0.7 & & & & $1(100)$ & $1(100)$ & \\
\hline Pantoea spp. & 1 & 0.7 & & & $1(100)$ & & & \\
\hline Staphylococcus warneri & 1 & 0.7 & & & & & $1(100)$ & $1(100)$ \\
\hline Total & 141 & 100 & $45(31.9)$ & $29(20.6)$ & $53(37.6)$ & $38(27)$ & $43(30.5)$ & $21(14.9)$ \\
\hline
\end{tabular}

Regarding cluster dynamics, Figures 1 and 2 verify that the same species were identified in different clusters, representing the different genetic profiles of the isolates determined by the polymorphic profile variables in the amplicons of the ITS region and, consequently, by the restriction products from the enzyme $C f_{o} \mathrm{I}$. The high genetic variability of deteriorating psychrotrophs was also observed by Martins et al. (2006) using genetic grouping by profile in random amplified polymorphic DNA.

The species Lactococcus lactis, Enterobacter kobei, Aerococcus urinaeequi, Acinetobacter lwoffii, Kurthia gibsonii, and S. ureilytica predominated among the deteriorating psychrotrophic microbiota of the raw milk from this sample unit. It can also be observed that gram-positive deteriorating microorganisms were also predominant $(58.2 \%)$; these organisms are often related to the initial and desirable microbiota of milk, as well as to the environment of the stables, feed for the animals, and infections of the mammary gland.

In Table 2, it is possible to observe that the species E. kobei (18.6\%), S. ureilytica (16.7\%), A. urinaeequi (14\%), and L. lactis $(9.3 \%)$ predominated among the microorganisms that presented simultaneous proteolytic and lipolytic activity at mesophilic incubation. Among the 45 isolates that showed only proteolytic activity, the most frequently observed species were L. lactis
(44.4\%), E. kobei (11.1\%), B. licheniformis (11.1\%), K. gibsonii $(8.9 \%)$ and $M$. caseolyticus (8.9\%), and of the 53 purely lipolytic isolates, L. lactis (20.8\%), E. kobei (17\%), A. lwoffii (13.2\%), A. urinaeequi (11.3\%), and S. epidermidis $(7.5 \%)$ predominated.

Considering the deterioration potential at refrigeration temperature, the predominant species were $S$. ureilytica $(75 \%)$, A. urinaeequi $(13.6 \%)$, and L. lactis $(8.6 \%)$ for simultaneous proteolytic and lipolytic activity, L. lactis (51.4\%) and A. urinaeequi (25\%) among the proteolytic psychrotrophs, and A. lwoffii (88.9\%) and E. kobei (31.9\%) among the lipolytics.

The 88 proteolytic isolates at mesophilic incubation were tested for alkaline metalloprotease production potential, and $15(17 \%)$ showed a positive PCR reaction for the $\operatorname{apr} X$ gene. Of these, $5(33.3 \%)$ were identified as S. ureilytica, $5(33.3 \%)$ as E. kobei, $2(13.3 \%)$ as Pseudomonas spp., 1 (6.7\%) as A. urinaeequi, 1 (6.7\%) as $Y$. enterocolitica, and $1(6.7 \%)$ as Stenotrophomonas rhizophila.

Alkaline metalloprotease production is generally related to the microorganisms of the genus Pseudomonas, and mainly to the species P. fluorescens (Scatamburlo et al., 2015). Pseudomonas has been reported as predominant among the deteriorating psychrotrophs of refrigerated raw milk (von Neubeck et al., 2015; Xin et al., 2017). In the present study, only $1.4 \%$ of the 


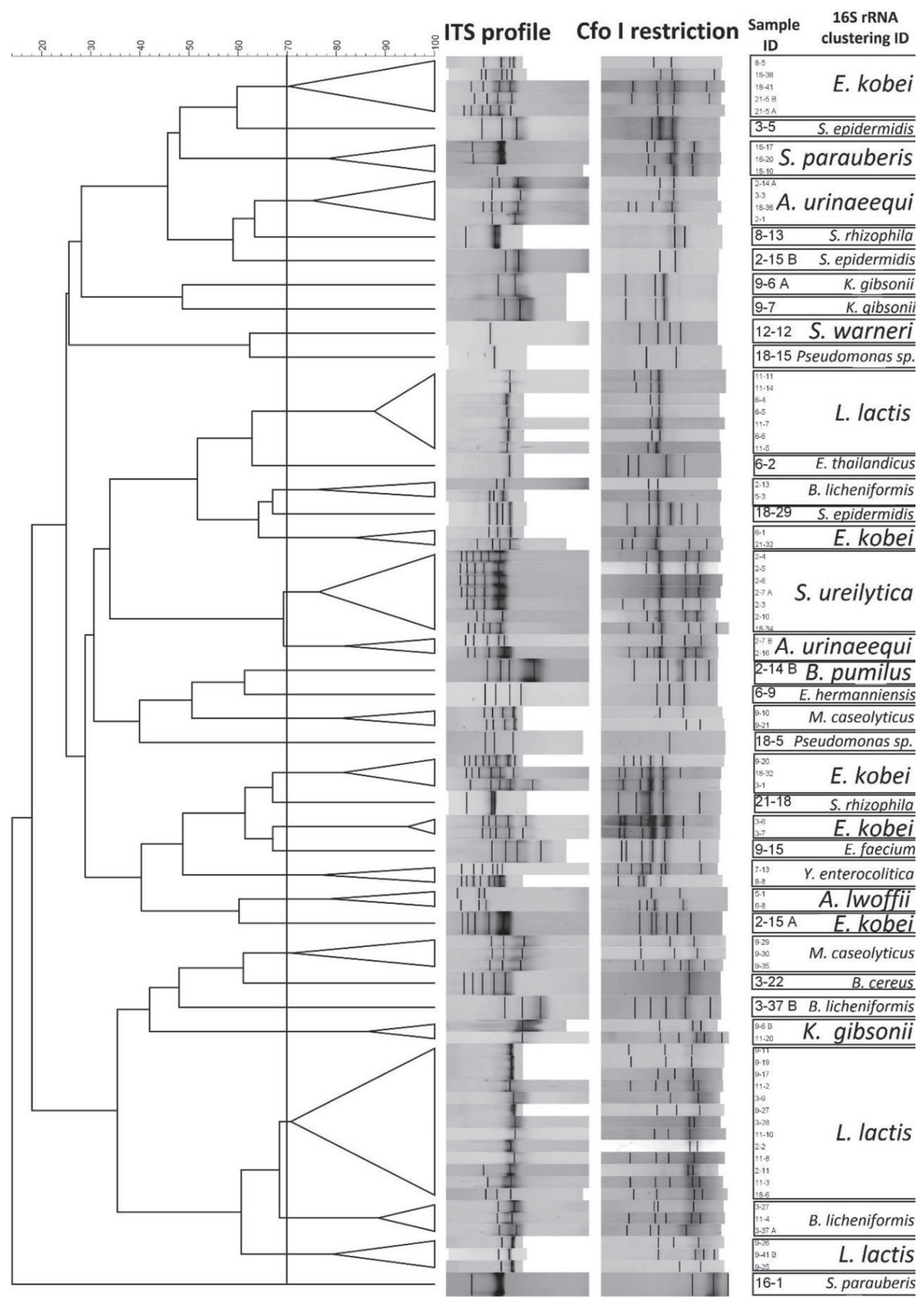

Figure 1. A phylogenetic similarity dendrogram of proteolytic psychrotrophic bacteria isolated from Brazilian raw milk, using the variables of the amplification profile of the internal transcript spacer region 16-23S (ITS profile) and its restriction profile with the enzyme Cfo I, Dice coefficient, and the unweighted pair group mean averages algorithm. The vertical line represents the minimum percentage of similarity (70\%) used to determine the 36 clusters. 


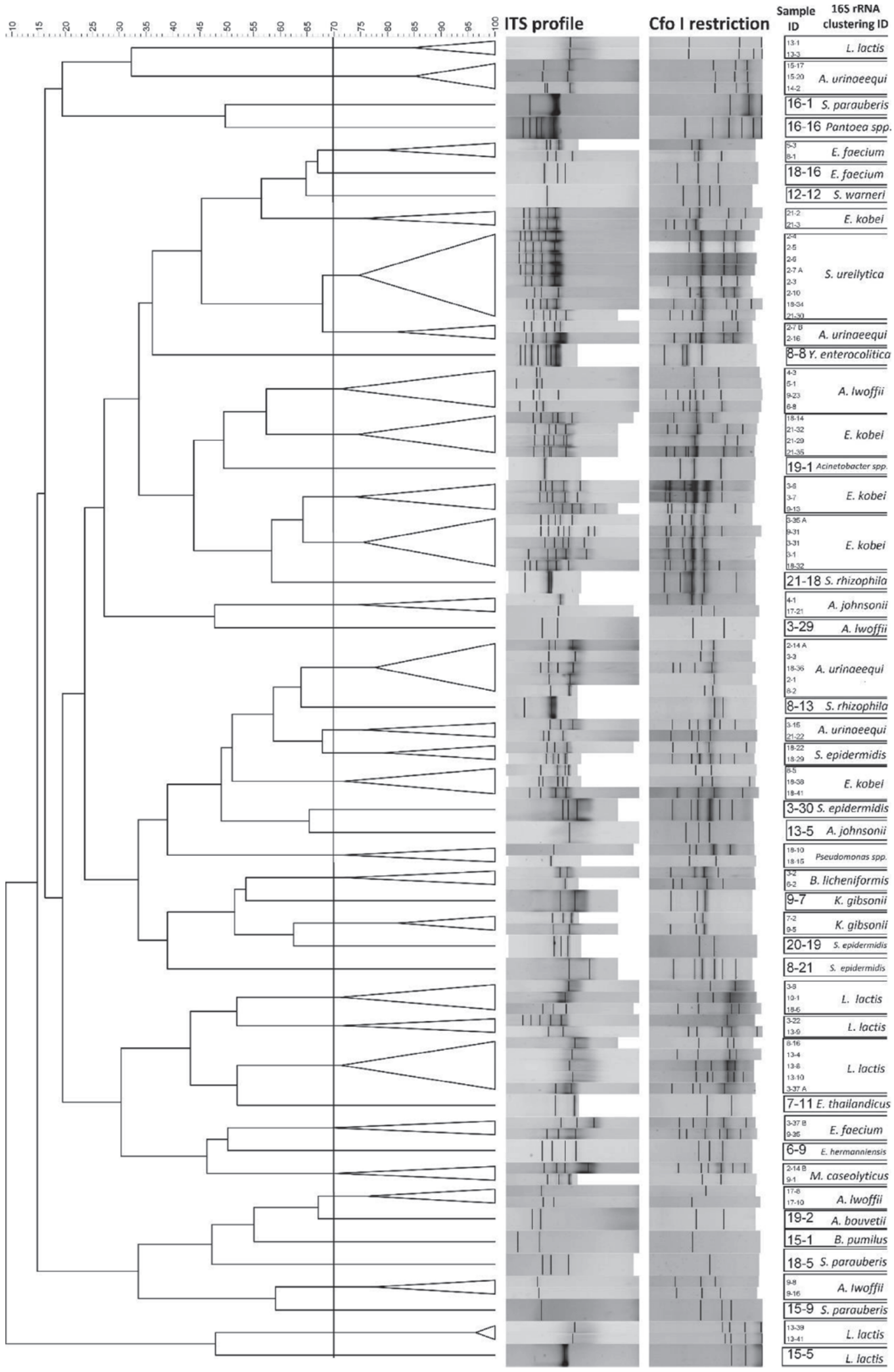

Figure 2. A phylogenetic similarity dendrogram of lipolytic psychrotrophic bacteria isolated from Brazilian raw milk prepared using the variables of the amplification profile of the internal transcript spacer region 16-23S (ITS profile) and its restriction profile with the enzyme Cfo I, Dice coefficient, and the unweighted pair group mean averages algorithm. The vertical line represents the minimum percentage of similarity $(70 \%)$ used to determine the 47 clusters. 
deteriorating psychrotrophic microbiota from the milk was of the Pseudomonas genus (Table 2), and the 2 isolates presented a positive result for the $\operatorname{apr} X$ gene. The low frequency of the genus Pseudomonas in the evaluated milk samples can be explained by the good microbiological conditions present while obtaining the milk and by the farm properties' use of treated water with low environmental contamination.

Considering the totality of the evaluated psychrotrophic microbiota (141 isolates) from refrigerated raw milk, the predominance of 35 strains $(24.5 \%)$ identified as L. lactis was observed, of which $68.6 \%$ presented proteolytic activity and $42.9 \%$ presented lipolytic capacity in plaques incubated at mesophilic temperature. In psychrotrophic conditions, 51.4 and $17.1 \%$ are proteolytic and lipolytic, respectively. In contrast, Ercolini et al. (2009) did not verify the proteolytic activity of the isolates of L. lactis, nor their growth at $7^{\circ} \mathrm{C}$, demonstrating that the expression of deteriorating enzymes or the temperature of multiplication can vary according to the strain of the microorganism.

The refrigerated raw milk samples evaluated in the present study were obtained from dairy farms that have good hygiene conditions at milking and a consistent investment in milk quality (Ribeiro Júnior et al., 2015). It was expected that lactic acid bacteria such as $L$. lactis (Holzapfel et al., 2001) would predominate, as these microorganisms constitute the autochthonous and desirable microbiota of milk; in contrast, milks with higher TBC generally show a predominance of gramnegative psychrotrophic microorganisms (Sørhaug and Stepaniak, 1997; McPhee and Griffiths, 2011; de Oliveira et al., 2015; Xin et al., 2017).

In addition to lactic acid bacteria, other microorganisms were evaluated in the present study; these may have originated from cases of mastitis, a common disease in high production animals (such as those in dairy farms) and include Staphylococcus (Felipe et al., 2017; Guimarães et al., 2017), Streptococcus (Taponen et al., 2017), and Aerococcus (Saishu et al., 2015).

Bacillus is another psychrotrophic gram-positive microorganism associated with spoilage identified in the present study; the species B. licheniformis and B. pumilus are psychrotrophic, frequently reported as thermoduric and thermophilic sporulated microorganisms (Huck et al., 2007; Buehner et al., 2014; Pinto et al., 2017), and found in DM such as silage (Gleeson et al., 2013; Buehner et al., 2014). These microorganisms have an influence on the shelf life of pasteurized milk.

Contamination of milk by gram-negative microorganisms is usually associated with a humid environment, equipment, and the water used to clean the systems for obtaining and storing milk (Dogan and Boor, 2003; de Oliveira et al., 2015). The small number of gramnegative microorganisms identified among the spoilage psychrotrophs in the present study reaffirms the good environmental hygiene conditions present while obtaining the raw milk.

It was verified that $87.5 \%$ of the isolates identified as S. ureilytica presented proteolytic and lipolytic activity at $35^{\circ} \mathrm{C} / 48 \mathrm{~h}$ and $75 \%$ at $7^{\circ} \mathrm{C} / 10 \mathrm{~d}$. This species was also the one showing the highest frequency of the $\operatorname{apr} X$ gene, which makes it a potential producer of alkaline metalloprotease. According to Baglinière et al. (2017), Serratia strains are able to synthesize 2 types of proteases, Ser1 and Ser2. Ser2 has an effect similar to the alkaline metalloprotease produced in the expression of the $\operatorname{apr} X$ gene, with a broad spectrum of action on caseins and implications for the shelf life of UHT milk. However, a study by Ercolini et al. (2009) reports proteolytic activity of $S$. marcescens at only 20 and $30^{\circ} \mathrm{C}$, not at $7^{\circ} \mathrm{C}$. This result demonstrates the intermittence of protease synthesis and the possible temperature interference, among other factors, in the expression of the apr $X$ gene.

Enterobacter kobei was the primary psychrotrophic gram-negative microorganism in the raw refrigerated milk isolated in the present work, representing $15.4 \%$ of the microbiota (Table 2). Of the isolates of this species, $22.7 \%$ were positive for the alkaline metalloprotease production potential ( $\operatorname{apr} X$ gene). This species was also the most frequently identified among lipolytic psychrotrophic microorganisms. Considering the totality of the psychrotrophic microbiota of raw milk, Ntuli et al. (2016) identified E. kobei in $0.8 \%$ of the 479 isolates. This bacterium belongs to the family Enterobacteriace$a e$, making it possible that the raw milk in the present study was contaminated directly or indirectly by feces. In confined spaces, which is the condition of the cows in this sample unit, udder contact with feces is frequent, and in these cases, increased attention should be paid to pre-dipping and elimination of the first milk jets.

Another enterobacterium that was found, Y. enterocolitica, is an important pathogen (Oliver et al., 2009), and usually uses the swine as its reservoir. In fact, there are several pig farms in the region of the present study. The proteolytic activity on the plaques and the alkaline metalloprotease $(\operatorname{apr} X)$ production potential of this microorganism can compromise the quality of milk and dairy products, and its pathogenicity reaffirms the risk of consuming raw dairy products. In some regions of Brazil, the consumption of raw milk or of products made from raw milk is still frequent, as raw milk consumption is perceived to be safe. The study by Pieri et al. (2014) reports that $18.5 \%$ of the Brazilians interviewed regularly consume milk and raw products. 


\section{CONCLUSIONS}

Despite the reduction of initial bacterial counts in raw milk to very low levels, the activity of heat-stable proteases, including alkaline metalloprotease, and of lipolytic enzymes originating from psychrotrophic bacteria is the limiting factor in maintaining the quality of fluid milk and its products. Interestingly, the highest deteriorating activity of the psychrotrophs was verified at mesophilic temperature, and gram-positive microorganisms predominate among the psychrotrophs with spoilage potential, L. lactis being the most prevalent species. Moreover, as expected, infectious agents of mastitis and spore-forming organisms have also been identified among the deteriorating psychrotrophs, and these can also reduce the shelf life of pasteurized milk. Therefore, it is necessary to develop sensitive and efficient tools to monitor and control their presence in raw milk.

\section{ACKNOWLEDGMENTS}

The team of the present work thanks the National Council for Scientific and Technological Development (CNPq, Brasilia, Brazil) and the Regional Center for Excellence in Milk Technology-North Central (Londrina, Brazil) for the financial support, the collaboration of the Brazilian Agricultural Research Corporation (EMBRAPA), Soy Unit, specifically the researchers Renan Augusto Ribeiro, Jakeline Renata Marçon Delamuta, and Mariangela Hungria da Cunha for training the team in Bionumerics software.

\section{REFERENCES}

Andersson, I., and R. Öste. 1994. Nutritional quality of pasteurized milk. Vitamin B12, folate and ascorbic acid content during storage. Int. Dairy J. 4:161-172. https://doi.org/10.1016/0958 $-6946(94) 90066-3$.

Bach, H. J., A. Hartmann, M. Schloter, and J. C. Munch. 2001. PCR primers and functional probes for amplification and detection of bacterial genes for extracellular peptidases in single strains and in soil. J. Microbiol. Methods 44:173-182. https://doi.org/10.1016/ S0167-7012(00)00239-6.

Baglinière, F., J. Jardin, F. Gaucheron, A. F. de Carvalho, and M. C. D. Vanetti. 2017. Proteolysis of casein micelles by heat-stable protease secreted by Serratia liquefaciens leads to the destabilisation of UHT milk during its storage. Int. Dairy J. 68:38-45. https://doi .org/10.1016/j.idairyj.2016.12.012.

Buehner, K. P., S. Anand, G. D. Djira, and A. Garcia. 2014. Prevalence of thermoduric bacteria and spores on 10 Midwest dairy farms. J. Dairy Sci. 97:6777-6784. https://doi.org/10.3168/jds $.2014-8342$.

Cousin, M. A. 1982. Presence and activity of psychrotrophic microorganisms in milk and dairy products: A review. J. Food Prot. 45:172-207.

Das, B., A. P. Roy, S. Bhattacharjee, S. Chakraborty, and C. Bhattacharjee. 2015. Lactose hydrolysis by $\beta$-galactosidase enzyme: Optimization using response surface methodology. Ecotoxicol. En- viron. Saf. 121:244-252. https://doi.org/10.1016/j.ecoenv.2015.03 .024 .

de Oliveira, G. B. D., L. Favarin, R. H. Luchese, and D. McIntosh. 2015. Psychrotrophic bacteria in milk: How much do we really know? Braz. J. Microbiol. 46:313-321. https://doi.org/10.1590/ S1517-838246220130963.

Dice, L. R. 1945. Measures of the amount of ecologic association between species. Ecology 26:297-302. https://doi.org/10.2307/ 1932409.

Dogan, B., and K. J. Boor. 2003. Genetic diversity and spoilage potentials among Pseudomonas spp. isolated from fluid milk products and dairy processing plants. Appl. Environ. Microbiol. 69:130-138. https://doi.org/10.1128/AEM.69.1.130-138.2003.

Edwards, U., T. Rogall, H. Blöcker, M. Emde, and E. C. Böttger. 1989. Isolation and direct complete nucleotide determination of entire genes. Characterization of a gene coding for $16 \mathrm{~S}$ ribosomal RNA. Nucleic Acids Res. 17:7843-7853. https://doi.org/10.1093/ nar/17.19.7843.

Ercolini, D., F. Russo, I. Ferrocino, and F. Villani. 2009. Molecular identification of mesophilic and psychrotrophic bacteria from raw cow's milk. Food Microbiol. 26:228-231. https://doi.org/10.1016/ j.fm.2008.09.005.

Erich, S., B. Kuschel, T. Schwarz, J. Ewert, N. Böhmer, F. Niehaus, J. Eck, S. Lutz-Wahl, T. Stressler, and L. Fischer. 2015. Novel highperformance metagenome $\beta$-galactosidases for lactose hydrolysis in the dairy industry. J. Biotechnol. 210:27-37. https://doi.org/10 $.1016 /$ j.jbiotec.2015.06.411.

Fairbairn, D. J., and B. A. Law. 1986. Proteinases of psychrotrophic bacteria: Their production, properties, effects and control. J. Dairy Res. 53:139-177. https://doi.org/10.1017/S0022029900024742.

Felipe, V., C. A. Morgante, P. S. Somale, F. Varroni, M. L. Zingaretti, R. A. Bachetti, S. G. Correa, and C. Porporatto. 2017. Evaluation of the biofilm forming ability and its associated genes in Staphylococcus species isolates from bovine mastitis in Argentinean dairy farms. Microb. Pathog. 104:278-286. https://doi.org/10.1016/j .micpath.2017.01.047.

Gargouri, A., H. Hamed, and A. ElFeki. 2013. Analysis of raw milk quality at reception and during cold storage: Combined effects of somatic cell counts and psychrotrophic bacteria on lipolysis. J. Food Sci. 78:M1405-M1411. https://doi.org/10.1111/1750-3841 .12188 .

Gleeson, D., A. O'Connell, and K. Jordan. 2013. Review of potential sources and control of thermoduric bacteria in bulk-tank milk. Ir. J. Agric. Food Res. 52:217-227.

Guimarães, F. F., M. P. Manzi, S. F. Joaquim, V. B. Richini-Pereira, and H. Langoni. 2017. Short communication: Outbreak of methicillin-resistant Staphylococcus aureus (MRSA)-associated mastitis in a closed dairy herd. J. Dairy Sci. 100:726-730. https://doi.org/ 10.3168/jds.2016-11700.

Hall, T. A. 1999. BioEdit: A user-friendly biological sequence alignment editor and analysis program for Windows 95/98/NT. Nucl. Acids Symp. Ser. 41:95-98.

Hantsis-Zacharov, E., and M. Halpern. 2007. Culturable psychrotrophic bacterial communities in raw milk and their proteolytic and lipolytic traits. Appl. Environ. Microbiol. 73:7162-7168. https:// doi.org/10.1128/AEM.00866-07.

Holzapfel, W. H., P. Haberer, R. Geisen, J. Björkroth, and U. Schillinger. 2001. Taxonomy and important features of probiotic microorganisms in food and nutrition. Am. J. Clin. Nutr. 73:365S-373S.

Huang, X., and A. Madan. 1999. CAP3: A DNA sequence assembly program. Genome Res. 9:868-877. https://doi.org/10.1101/gr.9.9 .868 .

Huck, J. R., B. H. Hammond, S. C. Murphy, N. H. Woodcock, and K. J. Boor. 2007. Tracking spore-forming bacterial contaminants in fluid milk-processing systems. J. Dairy Sci. 90:4872-4883. https:// doi.org/10.3168/jds.2007-0196.

Kumar, S., G. Stecher, and K. Tamura. 2016. MEGA7: Molecular Evolutionary Genetics Analysis version 7.0 for bigger datasets. Mol. Biol. Evol. 33:1870-1874. https://doi.org/10.1093/molbev/ msw054. 
Martins, M. L., C. L. Pinto, R. B. Rocha, E. F. de Araujo, and M. C. Vanetti. 2006. Genetic diversity of Gram-negative, proteolytic, psychrotrophic bacteria isolated from refrigerated raw milk. Int. J. Food Microbiol. 111:144-148. https://doi.org/10.1016/j .ijfoodmicro.2006.06.020.

Matéos, A., M. Guyard-Nicodème, F. Baglinière, J. Jardin, F. Gaucheron, A. Dary, G. Humbert, and J. L. Gaillard. 2015. Proteolysis of milk proteins by AprX, an extracellular protease identified in Pseudomonas LBSA1 isolated from bulk raw milk, and implications for the stability of UHT milk. Int. Dairy J. 49:78-88. https:// doi.org/10.1016/j.idairyj.2015.04.008.

Matta, H., V. Punj, and S. S. Kanwar. 1997. An immuno-dot blot assay for detection of thermostable protease from Pseudomonas sp. AFT-36 of dairy origin. Lett. Appl. Microbiol. 25:300-302. https://doi.org/10.1046/j.1472-765X.1997.00228.x.

McAuley, C. M., T. K. Singh, J. F. Haro-Maza, R. Williams, and R. Buckow. 2016. Microbiological and physicochemical stability of raw, pasteurised or pulsed electric field-treated milk. Innov. Food Sci. Emerg. Technol. 38:365-373. https://doi.org/10.1016/j.ifset 2016.09.030.

McPhee, J. D., and M. W. Griffiths. 2011. Psychrotrophic bacteria| Pseudomonas spp. Pages 379-383 in Encyclopedia of Dairy Sciences. W. F. John, ed. Academic Press, London, UK.

Normand, P., C. Ponsonnet, X. Nesme, M. Neyra, and P. Simonet. 1996. ITS analysis of prokaryotes, Pages 1-12 in Molecular Microbial Ecology Manual. D. L. Akkermans, J. D. Van Elsas, and E. I. De Bruijn, ed. Kluwer Academic Publishers, Dordrecht, the Netherlands.

Ntuli, V., P. M. K. Njage, and E. M. Buys. 2016. Characterization of Escherichia coli and other Enterobacteriaceae in producer-distributor bulk milk. J. Dairy Sci. 99:9534-9549. https://doi.org/10 3168/jds.2016-11403.

Oliver, S. P., K. J. Boor, S. C. Murphy, and S. E. Murinda. 2009. Food safety hazards associated with consumption of raw milk. Foodborne Pathog. Dis. 6:793-806. https://doi.org/10.1089/fpd.2009 .0302 .

Osborne, C. A., M. Galic, P. Sangwan, and P. H. Janssen. 2005. PCRgenerated artefact from $16 \mathrm{~S}$ rRNA gene-specific primers. FEMS Microb. Let. 248:183-187. https://doi.org/10.1016/j.femsle.2005 .05 .043 .

Pieri, F. A., M. Colombo, C. M. Merhi, V. A. Juliati, M. S. Ferreira, M. A. Nero, and L. A. Nero. 2014. Risky consumption habits and safety of fluid milk available in retail sales outlets in Viçosa, Minas Gerais State, Brazil. Foodborne Pathog. Dis. 11:490-496. https:// doi.org/10.1089/fpd.2013.1712.

Pinto, C. L., L. V. Souza, V. A. Meloni, C. S. Batista, R. Silva, E. M. Martins, A. Cruz, and M. L. Martins. 2017. Microbiological quality of Brazilian UHT milk: Identification and spoilage potential of spore-forming bacteria. Int. J. Dairy Technol. 70:1-7. https://doi .org/0.1111/1471-0307.12339.

Ranjard, L., F. Poly, J. C. Lata, C. Mougel, J. Thioulouse, and S. Nazaret. 2001. Characterization of bacterial and fungal soil communities by automated ribosomal intergenic spacer analysis fingerprints: Biological and methodological variability. Appl. Envi- ron. Microbiol. 67:4479-4487. https://doi.org/10.1128/AEM.67.10 .4479-4487.2001.

Ribeiro Júnior, J. C., R. Tamanini, L. C. C. da Silva, and V. Beloti. 2015. Quality of milk produced by small and large dairy producers. Semin. Cienc. Agrar. 36:883-888. https://doi.org/10.5433/ 1679-0359.2015v36n2p883.

Ribeiro Júnior, J. C., R. Tamanini, B. F. Soares, A. M. de Oliveira, F. G. Silva, F. F. da Silva, N. A. Augusto, and V. Beloti. 2016. Efficiency of boiling and four other methods for genomic DNA extraction of deteriorating spore-forming bacteria from milk. Semin. Cienc. Agrar. 37:3069-3078. https://doi.org/10.5433/1679-0359 .2016v37n5p3069.

Saishu, N., K. Morimoto, H. Yamasato, H. Ozaki, and T. Murase. 2015. Characterization of Aerococcus viridans isolated from milk samples from cows with mastitis and manure samples. J. Vet. Med. Sci. 77:1037-1042. https://doi.org/10.1292/jvms.15-0100.

Samarzija, D., S. Zamberlin, and C. T. Pogaci. 2012. Psychrotrophic bacteria and milk and dairy products quality. Mljekarstvo 62:7795 .

Scatamburlo, T. M., A. K. Yamazi, V. Q. Cavicchioli, F. A. Pieri, and L. A. Nero. 2015. Spoilage potential of Pseudomonas species isolated from goat milk. J. Dairy Sci. 98:759-764. https://doi.org/ 10.3168/jds.2014-8747.

Sneath, P. H., and R. R. Sokal. 1973. Numerical Taxonomy: The Principles and Practice of Numerical Classification. W.H. Freeman and Company, San Francisco, CA

Sørhaug, T., and L. Stepaniak. 1997. Psychrotrophs and their enzymes in milk and dairy products: Quality aspects. Trends Food Sci Technol. 8:35-41. https://doi.org/10.1016/S0924-2244(97)01006-6.

Taponen, S., E. Liski, A. M. Heikkilä, and S. Pyörälä. 2017. Factors associated with intramammary infection in dairy cows caused by coagulase-negative staphylococci, Staphylococcus aureus, Streptococcus uberis, Streptococcus dysgalactiae, Corynebacterium bovis, or Escherichia coli. J. Dairy Sci. 100:493-503. https://doi.org/10 .3168/jds.2016-11465.

Vithanage, N. R., M. Dissanayake, G. Bolge, E. A. Palombo, T. R. Yeager, and N. Datta. 2016. Biodiversity of culturable psychrotrophic microbiota in raw milk attributable to refrigeration conditions, seasonality and their spoilage potential. Int. Dairy J. 57:8090. https://doi.org/10.1016/j.idairyj.2016.02.042.

von Neubeck, M., C. Baur, M. Krewinkel, M. Stoeckel, B. Kranz, T. Stressler, L. Fischer, J. Hinrichs, S. Scherer, and M. Wenning. 2015. Biodiversity of refrigerated raw milk microbiota and their enzymatic spoilage potential. Int. J. Food Microbiol. 211:57-65. https://doi.org/10.1016/j.ijfoodmicro.2015.07.001.

Xin, L., Z. Meng, L. Zhang, Y. Cui, X. Han, and H. Yi. 2017. The diversity and proteolytic properties of psychrotrophic bacteria in raw cows' milk from North China. Int. Dairy J. 66:34-41. https:// doi.org/10.1016/j.idairyj.2016.10.014.

Zhang, S., H. Li, H. Uluko, L. Liu, X. Pang, and J. Lv. 2015. Investigation of protease production by Pseudomonas fluorescens BJ10 and degradation on milk proteins. J. Food Process. Preserv. 39:2466-2472. https://doi.org/10.1111/jfpp.12496. 